\title{
Analysis of the resistivity imaging results conducted over karst voids in Klucze using Depth of Investigation Index
}

\begin{tabular}{|l|l}
\hline Krajewska Olga & 'Student Science Society of Geophysics, Faculty of Earth Sciences, \\
Michał Glazer & University of Silesia, Będzinska 60, 41-200 Sosnowiec, \\
Pierwoła Jolanta & olga.rachwalik@gmail.com \\
& 2 Department of Geomorphology, Faculty of Earth Sciences, \\
& University of Silesia, Będzińska 60, 41-200 Sosnowiec, \\
& m.glazer@o2.pl \\
& 3.Department of Applied Geology, Faculty of Earth Sciences, \\
& University of Silesia, Będzińska 60, 41-200 Sosnowiec, \\
& jolanta.pierwola@us.edu.pl
\end{tabular}

\begin{abstract}
Conducted by "Olkusz" Speleological Club exploratory works related to the Gieńkówka cave led only to its partial opening. There are indications stating that this cave has continuation beyond its currently available parts. In order to verify those assumptions resistivity imaging method has been used. During analysis of the resistivity models obtained from field measurements the synthetic model, simulating the intersection of the cave corridor, has been utilized. In order to assess the reliability of resistivity cross sections in terms of the presence of artifacts left by the inversion process Depth of Investigation (DOI) index has been applied. For preparing DOI maps two inversions on the same data set were carried out using different reference models. Then the results were compared to each other.

High resistivity anomalies revealed on obtained models show strong correlation with actual caves known in this area. In addition, similar anomalies have been found in place of the predicted continuity in Gieńkówka cave, thus confirming the hypothesis made in this research. High DOI index values in the occurrence of caves pointing to the instability of the inversion process in those areas.
\end{abstract}

Key words: Resistivity Imaging, Depth of Investigation Index, karst caves, Klucze

DOI: $10.2478 / \mathrm{ctg}-2014-0018$

Received: $30^{\text {th }}$ June, 2014

Accepted: $4^{\text {th }}$ September, 2014

\section{Introduction}

Polish Jura Highland is characterized by one of the largest concentration of caves in Poland. Nearly 150 caves with a length over 40 meters were found there and new ones are still being discovered. The appraisal and exploration of the caves are conducted by experienced speleologists belonging to caving clubs including clubs from Olkusz and Czestochowa.
Existing techniques utilized for caves searched by speleological clubs are limited primarily to observations of area where the favorable conditions for their occurrence prevail. Entrances are mostly sought in winter time when warmer air from inside the caves causes melting of the snow cover on the surface. This may be a premise for the existence of karsts voids. 
On the territory of Klucze community, near Rodaki village, new caves have been discovered during the last few years. Now, after many exploratory expeditions they can be classified as one of the longest caves in the Polish Jura. They are Józef Cave and Rysia Cave. But beyond them there are a number of other, smaller voids. One of them is the Gieńkówka cave. Its opening has been found recently and only few explorations have been made so far. Few bats have been observed after opening the entrance hole for the first time, what indicate that this cave possess connection with another karst system in this region. Speleological Club Olkusz is engaged in exploration of this area. Members of this club have managed to access only few meters into the cave. Its currently recognized depth is 15 $\mathrm{m}$. The end section of the Gieńkówka cave has a very narrow slot and transition through it is now impossible due to its size. Behind slot there is a corridor, where floor descends to greater depths but so far nothing more has been documented. The inner recognition works have been stopped at this point. Premises about continuation of the Gieńkówka cave contributed to the usage of resistivity imaging method to confirm those assumptions. This method has been used for karst cave detection among others by Stepišnik and Mihevc (2008).

In cooperation with Speleological Club Olkusz, 6 survey profiles have been designated in order to confirm continuation of Gieńkówka cave as well as to study already known caves. Profiles have been located over the Józef and Rysia caves as well as over the final parts of Gieńkówka cave.

\section{Site characteristic}

The area of this study is placed in municipality of Klucze. It belongs to Krakow-Czestochowa Jurassic Highland. The location of measurements is situated near Rodaki village, on one of the nearby hills named Las Mountain. Rodaki are located near the provincial road No. 791, between Olkusz and Zawiercie (Fig.1). Geological fault zone Krakow-Lubliniec (SUKL), which is border between Malopolska and Upper Silesian block (Dadlez et al. 1994, Żaba 1999) extends in the vicinity of the place. Tectonic activity of this area lasted from early Paleozoic to modern times (Buła 2000, Morawska 1997, 1999, Jędrys 2007). The biggest influence on the local morphology have a diversity of facials in the Upper Jurassic limestone in which caves are formed, tectonic movements and of course, karst processes (Gradziński 1962, Jędrys 2007). Described area is composed of hills built from Upper Jurassic limestones and separated from each other by relatively wide depressions (Jędrys 2007). The presence of caves in this region is due to multistep processes of karst, which had started at the beginning of Paleogene. Most of those karst forms are found in rocky limestone and it is conditioned by the smallest content of clay minerals (Gradziński 1962, Jędrys 2007). Their inherency affects the inhibition of the water flow, thus karst processes are slowed down.

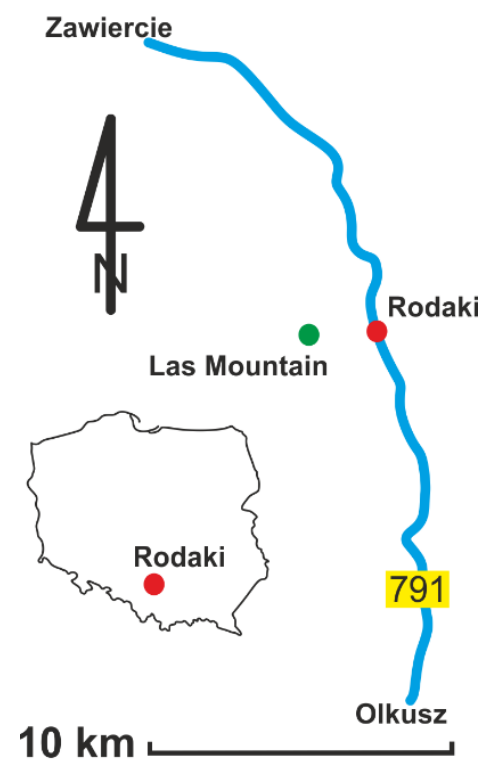

Fig.1. Approximate location of investigation site.

Most caves of Krakow - Czestochowa Jurassic system belongs to relict karst. It means that they were created in a completely different 
hydrogeological conditions than that prevail today. Therefore, they are only the fragments of ancient systems of water circulation (Gradziński 2013). They were developed in the sediments of the Upper Jurassic (Oxfordian), with an average thickness of 150-200 m and maximum to the $800 \mathrm{~m}$. The caves of the area have been created in crevices and clefts, which spread in the local hills and that were connected with extending near Krakow Lubliniec fault zone. The tectonic activity of this zone was related to, among others, intrusions of igneous rocks located between Małopolska and Upper Silesian block.

All caves of this region possess vertical development. Mentioned earlier Józef cave reaches a depth of 41 meters and its length is nearly $400 \mathrm{~m}$. It extends toward the west-east direction. Description of Rysia cave has not been published yet, so it's hard to determine its exact dimensions. Survey lines have been located in such a way that they would partially passed through the areas with already identified caves and the cave, which continuation is looked for (Fig. 2). Profile 1 passed over the Gieńkówka cave and has been placed on its end parts already explored by speleologist. Because the aim of the research was to find its continuation, thus further profiles have been moved in the north-west direction.

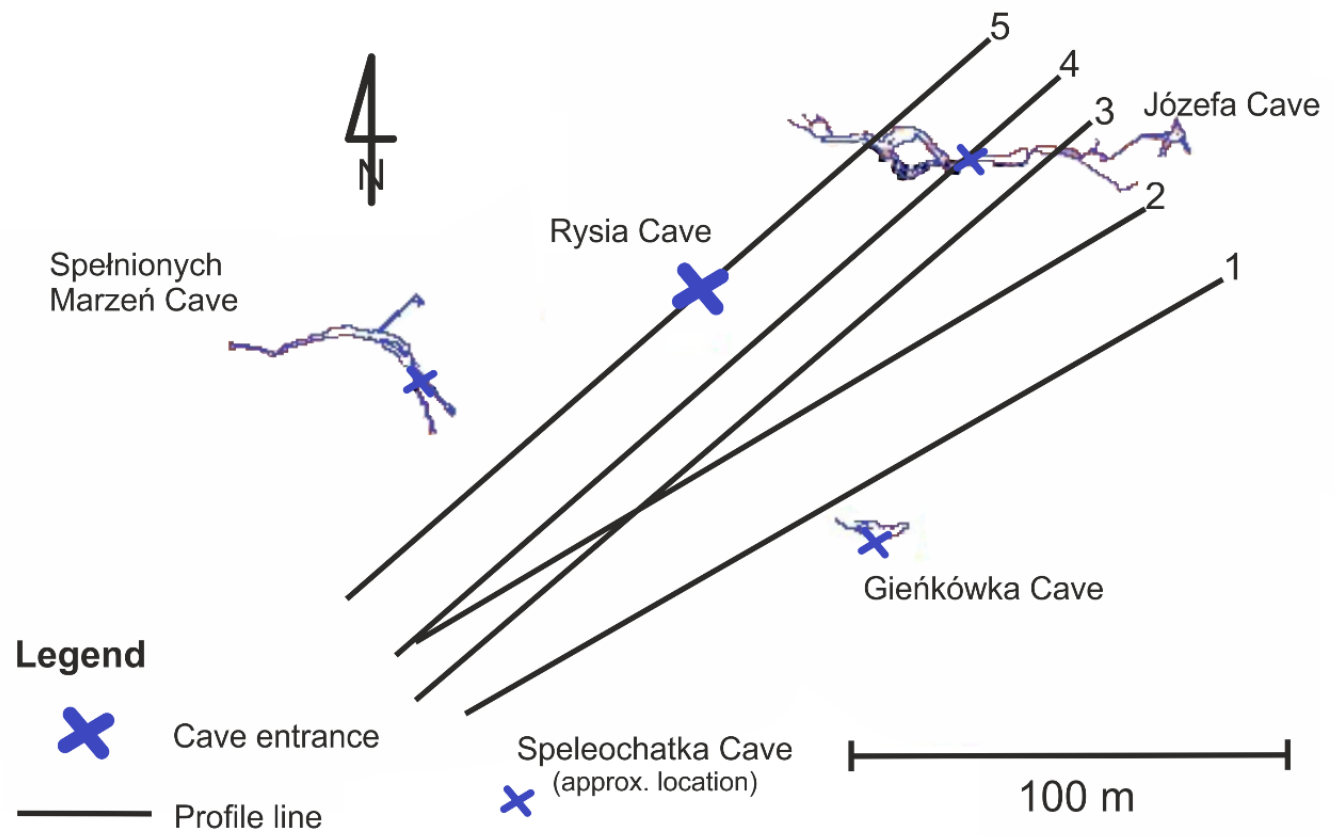

Fig.2. Arrangement of profiles on the Las mountain.

\section{Methodology}

Electrical Resistivity Tomography has been performed using ABEM Lund Imaging System. Five profile lines have been designated. It was an attempted to arrange them parallel and at equal distances from each other. As a result of complex morphology of the terrain and its thick vegetation cover, derogations from the primary assumptions could not have been avoided. The distance between two nearest profiles in the grid varies from 0 (where they intersect one another) to 30 m. On every survey lines two cables with 21 take-outs have been used with $5 \mathrm{~m}$ basic electrode spacing. Because both lateral and 
vertical resistivity variations were expected Wenner-Schlumberger protocol was applied (Loke 2014). Measurements have been performed after heavy rains what in combination with substantial soil cover ensured good ground-electrode contact. Significant denivelations on profile lines forced incorporation of morphology into the used modeling mesh process. Elevation data has been acquired from topographical maps in 1:1000 scale.

The inversion of resistivity data was carried out using Res2Dinv x64 ver. 4.03.13 program (RES2DINV manual, 2014). Caves as targets of this investigation indicate sharp resistivity changes in geological medium. This is the reason for utilization L1 norm smoothness constrained optimization method to generate resistivity models that in the best way would reconstruct orogen (Loke 2003). It is also known as blocky inversion method. It tends to minimize the absolute changes in model resistivity values. During initial processing no significant amount of data points have been erased. Additional weighting factors have been set at standard values for L1 norm in Res2Dinv.

To assess the solidity of the prepared models authors used an empirical Depth of Investigation (DOI) index method. In its core lies juxtaposition of two resistivity models created from the same data set for different reference models. In this way the information, about how much influence on final results have been made by parameters of optimization equation and not by the field data, is obtained. In places strongly dependent on measurements it will approach 0 , in contrast to 1 where parameters of inversion decides purely on the resistivity value (Oldenburg and $\mathrm{Li}, 1999$ ). DOI index value is determined for single cell of the prepared model. In next step, map of variations of this index is prepared and overlaid on resistivity model created without forcing the reference model. Single model cell
DOI value is given by (Oldenburg and Jones, 2007):

$$
\mathrm{R}_{\mathrm{AB}}(\mathrm{x}, \mathrm{z})=\frac{\left|\mathrm{q}_{\mathrm{A}}(\mathrm{x}, \mathrm{z})-\mathrm{q}_{\mathrm{B}}(\mathrm{x}, \mathrm{z})\right|}{\left|\mathrm{q}_{\mathrm{A}}-\mathrm{q}_{\mathrm{B}}\right|}
$$

where, with modification from Deceuster et al. (2014), $\mathrm{q}_{\mathrm{A}}(\mathrm{x}, \mathrm{z})$ and $\mathrm{q}_{\mathrm{B}}(\mathrm{x}, \mathrm{z})$ are the logarithms of model cell resistivity obtained from the first and second inversions, $\mathrm{q}_{\mathrm{A}}$ and $\mathrm{q}_{B}$ are the logarithm of first and second uniform reference models resistivity values.

Merescot et al. (2003) recommended using the reference models set at 0.1 and 10 times arithmetic mean of the measured apparent resistivity. This approach has been used in this study. Formation of DOI index map requires much wider model discretization than normal processing. It is due to the need of verification of DOI index behavior in the regions with minimal information on the resistivity of subsurface. The depth range of the inversion models has been extended 3.5 times the median depth of investigation of largest array spacing used for this purpose. All constructed DOI maps tended to increase its value above 0.9 in the bottom so there was no need for scaling the results. In RES2DINV software (RES2DINV manual, 2014) DOI preparation routine, the greatest value of damping factor $\mu$ responsible for impact on the reference model, was chosen. In this paper DOI maps have been trimmed to basic resistivity models.

Oldenburg and Li (1999) suggested 0.1 or 0.2 as the value of DOI index above which interpretation of resistivity models should not proceed. Oldenburg and Jones (2007) used index of 0.3 . In this paper DOI $=0.3$ has been chosen as the cut-off factor.

To check applied methodology synthetic model for Wenner-Schlumberger array with $5 \mathrm{~m}$ electrode spacing has been created in RES2DMOD software and subsequently analyzed with DOI index (Fig. 3). 


\section{Synthetic Model}

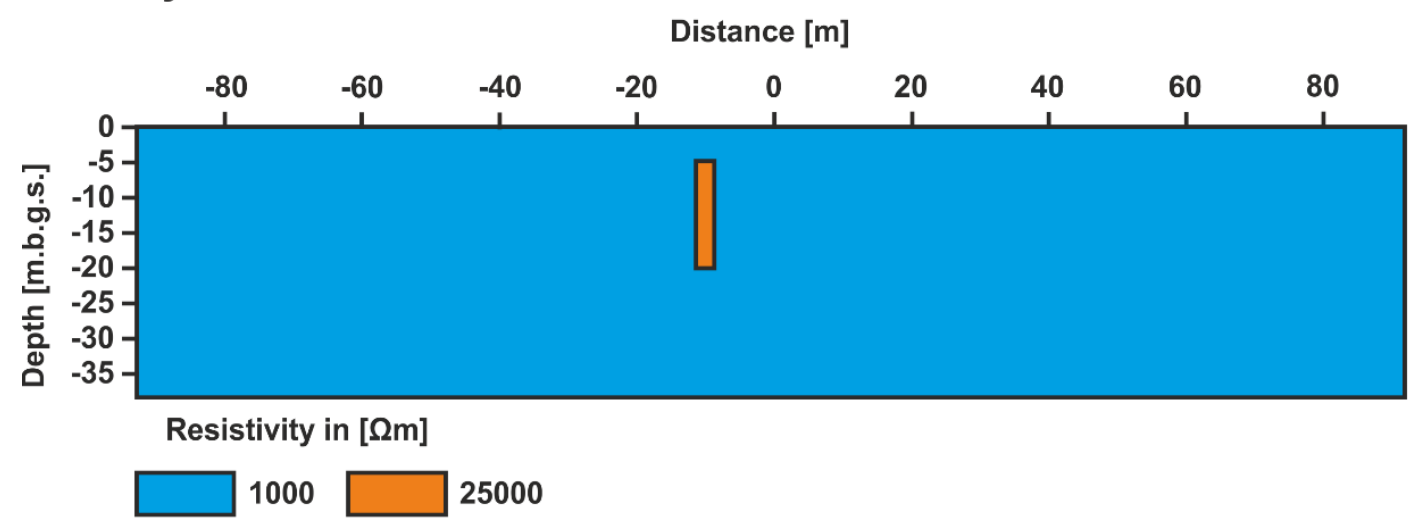

\section{Inversion results}

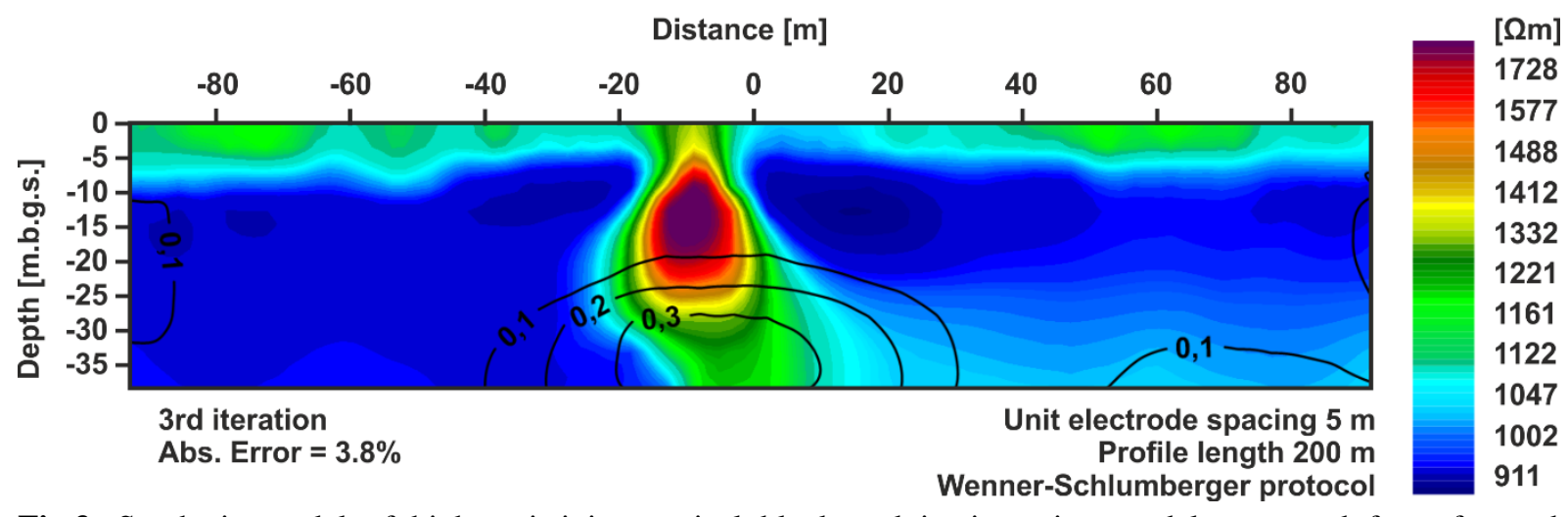

Fig.3. Synthetic model of high resistivity vertical block and its inversion model generated from forward modeling overlapped with DOI index map.

\section{Results - synthetic modeling}

Constructed model represents narrow vertical high resistivity block, which is an approximation of cave corridor. The data on geometrical dimensions have been taken from one of the known corridors of Józef cave. It roof lies at the depth of $5 \mathrm{~m}$. It is $2.5 \mathrm{~m}$ wide and $15 \mathrm{~m}$ high. Resistivity of the block has been set to $25000 \Omega \mathrm{m}$ and resistivity of the background has been given value of $1000 \Omega \mathrm{m}$ in order to match to the models obtained from measurements on investigation site. It resulted in anomaly that is over $20 \mathrm{~m}$ width and $25 \mathrm{~m}$ high. Its resistivity reaches $2000 \Omega \mathrm{m}$. Furthermore distortions just beneath the vertical block can be observed. In those parts DOI index value rise up significantly to 0.3 .

\section{Results - field data}

On resistivity cross sections starting from profile line 1 and finishing on 5 anomalously high resistivity areas are observed. They range from 2500 up to $8000 \Omega \mathrm{m}$. Their roofs are located at depth of 5 to $10 \mathrm{~m}$. On resistivity cross sections 2 to 4 (Fig.s 5 to 7), in their north eastern part, between 50 and $60 \mathrm{~m}$ of profile length, there is narrow direct connection to the surface. In profile 5 (Fig. 8) it spreads widely over $30 \mathrm{~m}$. Geometrical dimensions of the most of high resistivity anomalies are characterized by horizontal extension. Their thickness does not exceed 15 $\mathrm{m}$ while their width can reach values over 50 $\mathrm{m}$ if distinctions between successive maximums are considered. In most cases high resistivity anomalies surroundings varies from 
1000 to $1500 \Omega \mathrm{m}$. On the other hand, low resistivity areas with $200-700 \Omega m$ can be distinguished in two cases. First one is characterized by very thin thickness below 10 $\mathrm{m}$ and its emergence at the surface. It is clearly visible on resistivity cross sections of profile 1 (Fig. 4) in its south western part. On the next profiles it thins considerably but still, there is no doubt about its existence. Second one shows wide lateral distribution and is present in all the profiles under the level with high anomalies.
Imposed DOI maps on resistivity cross sections possess tendency to increase its values below high resistivity anomalies. On profiles 1 and 5 (Fig. 4 and 8) its maximum value reaches 0.3 . In these two profiles, DOI starts to increase under anomalies. In the other resistivity cross sections (Fig. 5 to 7) DOI can reach up to 0.5 and it begins to increase in areas directly occupied by high resistivity anomalies. It correlates well with their higher resistivity values and larger sizes.

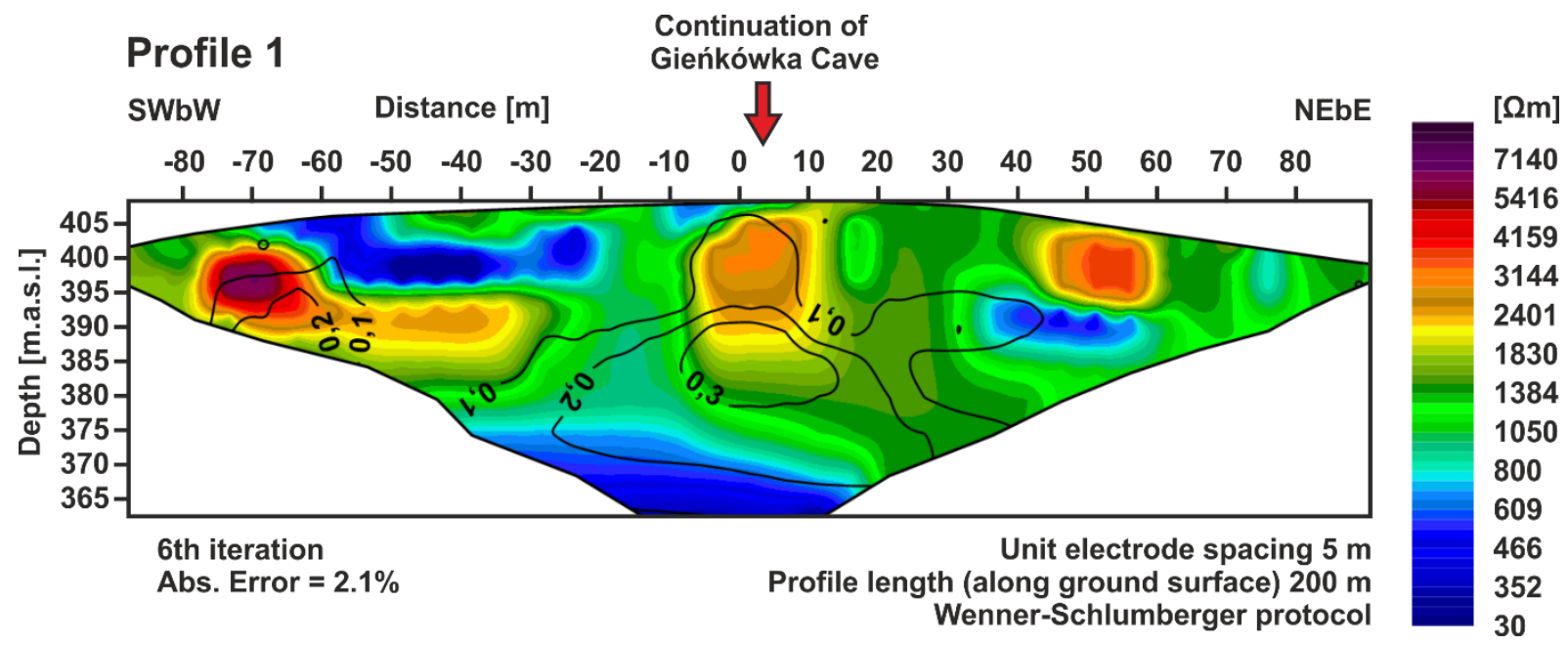

Fig.4. Resistivity cross-section from profile 1, overlapped with DOI index map.

\section{Profile 2}

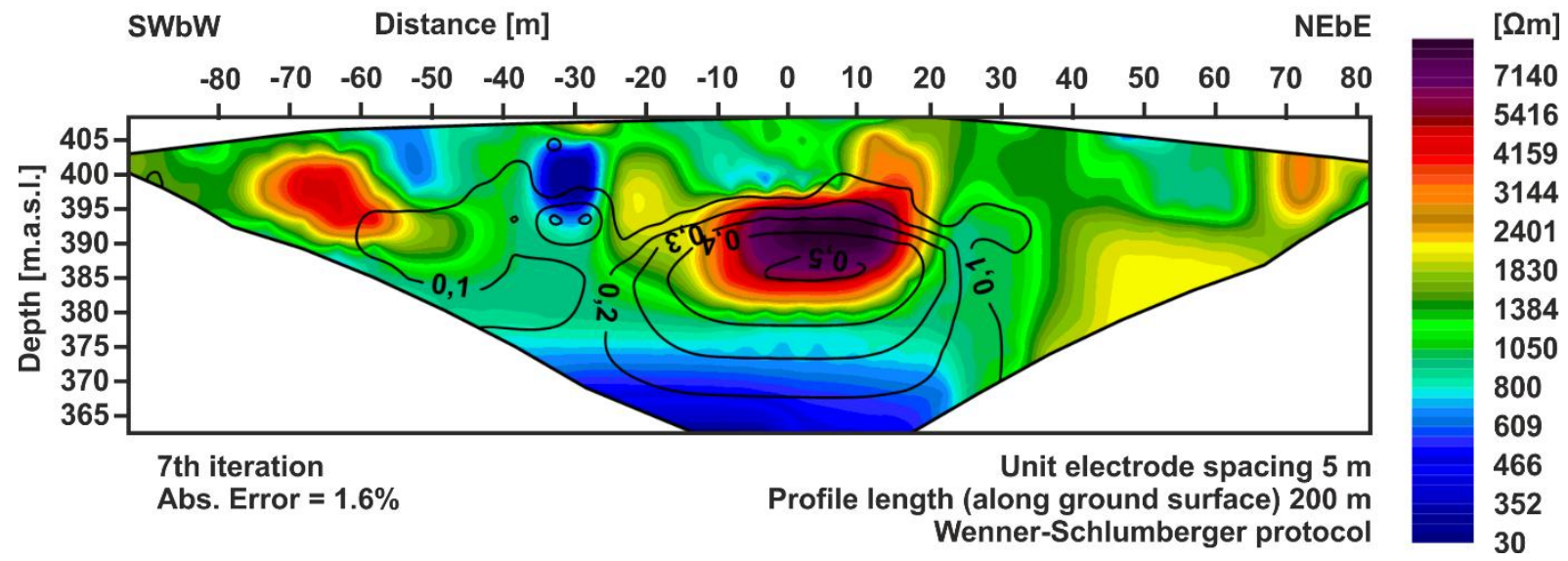

Fig.5. Resistivity cross-section from profile 2, overlapped with DOI index map. 


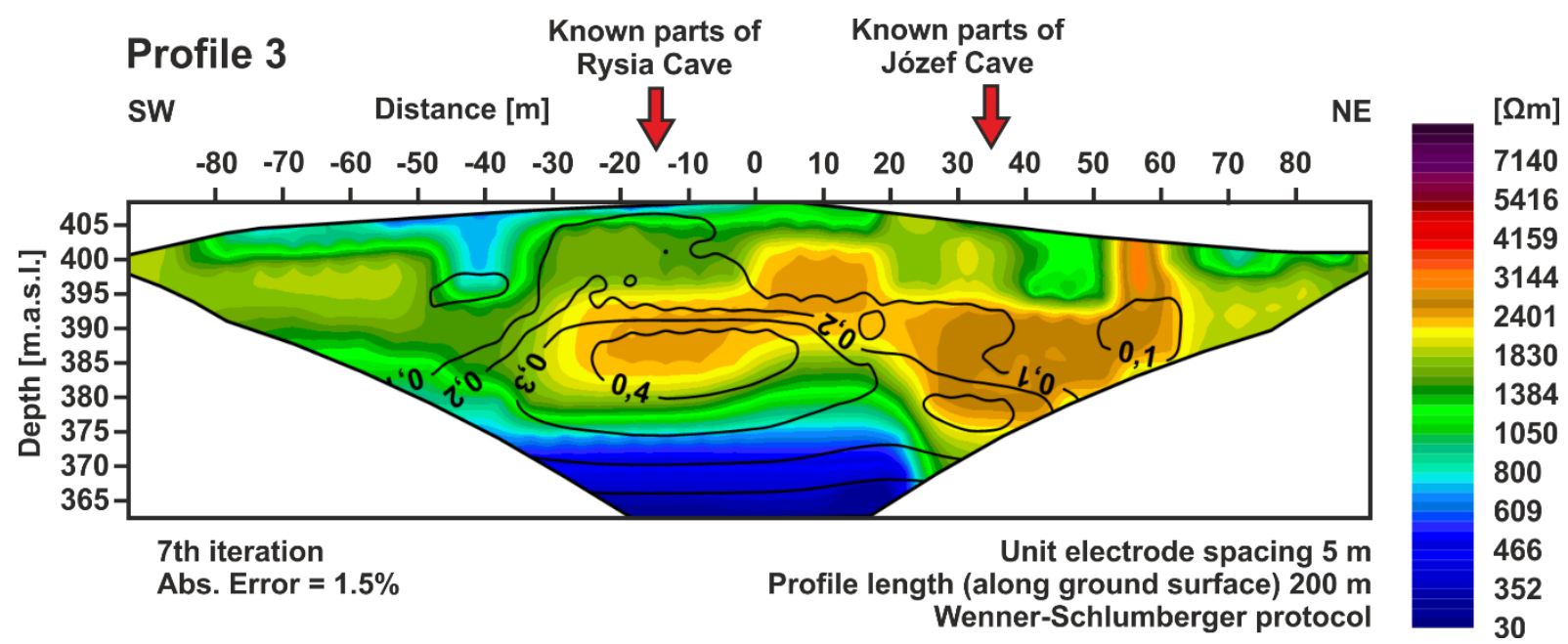

Fig.6. Resistivity cross-section from profile 3, overlapped with DOI index map.

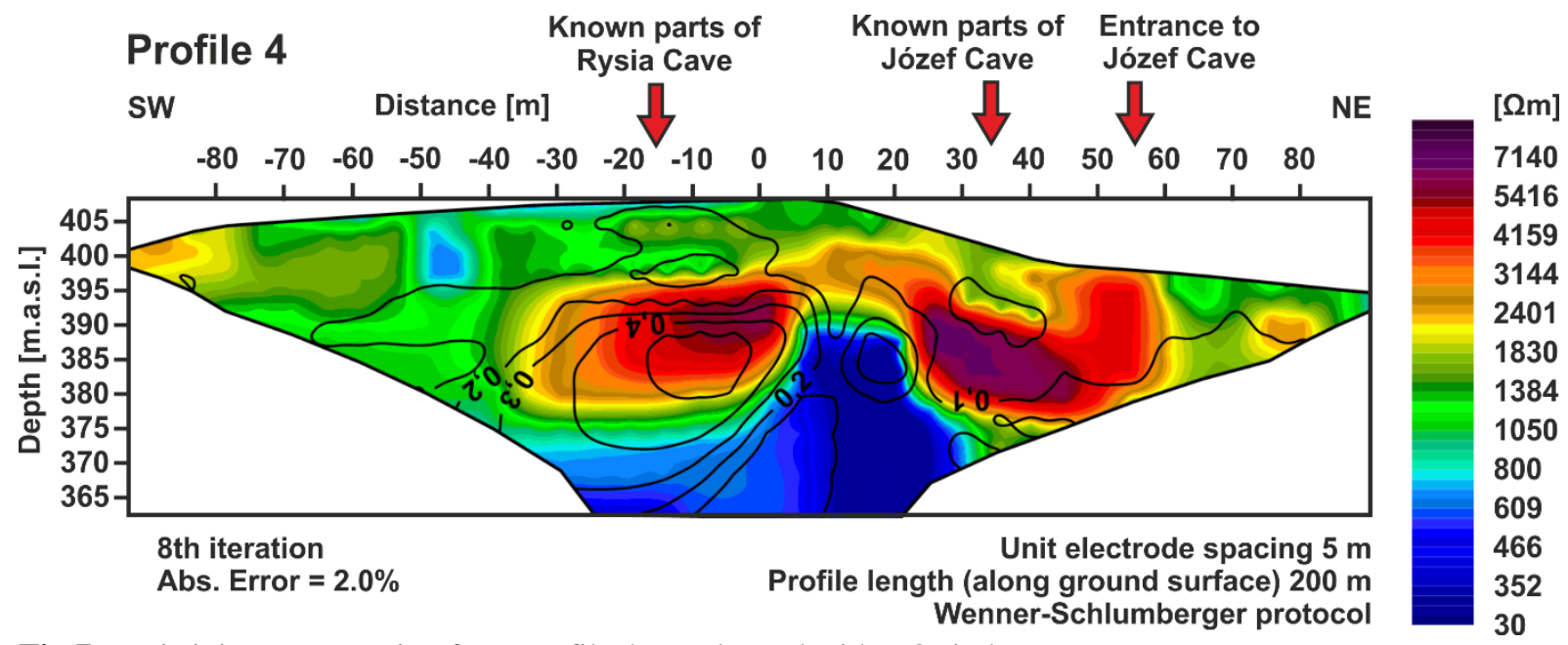

Fig.7. Resistivity cross-section from profile 4, overlapped with DOI index map.

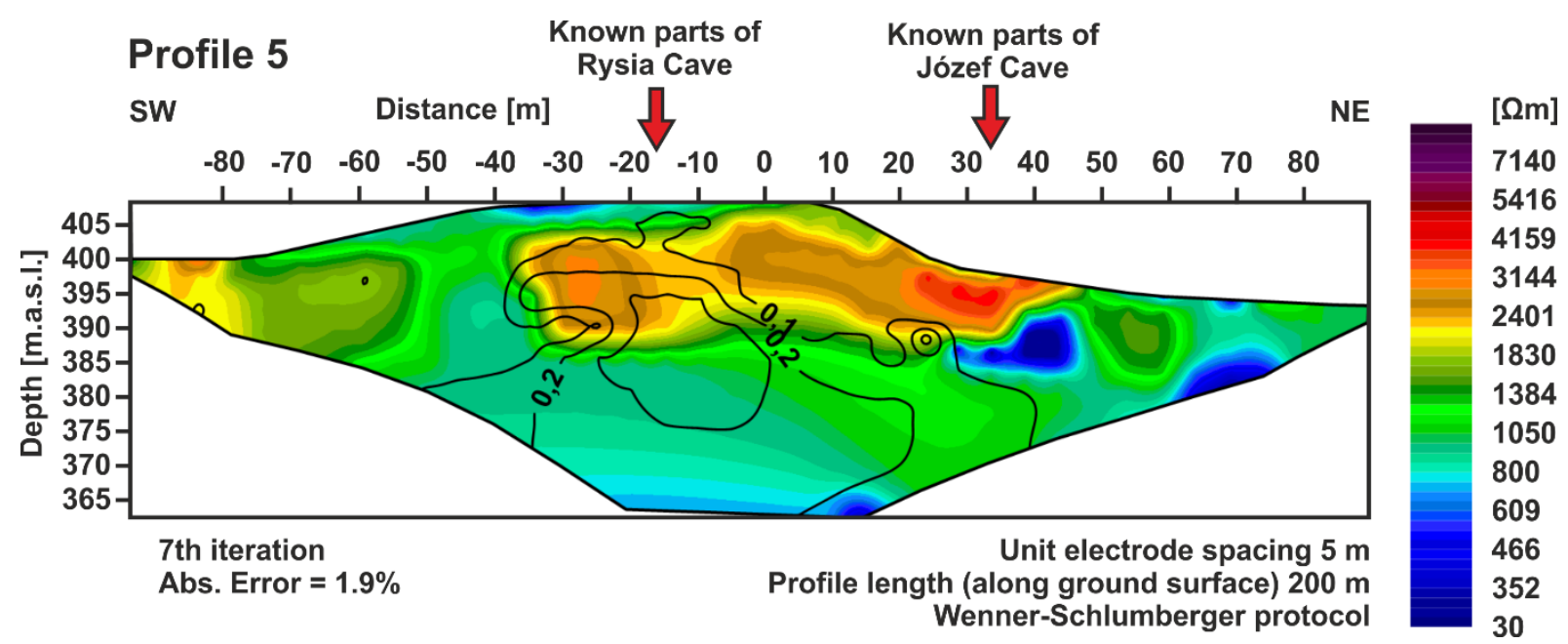

Fig.8. Resistivity cross-section from profile 5, overlapped with DOI index map. 


\section{Discussion and conclusions}

Despite that (Fig. 3) resistivity values used in synthetic modeling are not representative for voids in rock masses, received results represent well the type of anomaly which can be measured on karst cave corridor. It is important that geometrical dimensions are distorted. After inversion of field data, much wider anomaly is obtained. Its roof parts are well preserved in comparison with lower part. Furthermore additional distortions of the background are observed. They reach much deeper than the body that caused it. In those parts DOI value increase significantly, which gives direct information about increasing influence of parameters of objective function that has been used to construct inverse model. In this case it can be assumed that the interpretation should be stopped above 0.3 DOI index. It is also important to notice that in this case DOI is not sensitive on lateral extension of high resistivity anomaly. This is due to the physical limitations of the resistivity imaging method.

Underneath profile 1 (Fig. 4), which has been placed over the end of explored parts of Gieńkówka cave, speleologists encountered stenosis limiting further penetration of the cave. Anomaly recognized as Gieńkówka cave possesses DOI response that corresponds remarkably well with results of synthetic modeling (Fig. 3). In profile 2 (Fig. 5) that high resistivity anomaly takes even greater values of resistivity and lies deeper. The same thing happens with the DOI index. Additionally its maximum is placed directly in the area of anomaly. This not only means that Gieńkówka cave has its continuation but probably also that it becomes much wider and deeper. The anomaly that appears in southwestern part of the first resistivity cross section and diminish on the following profiles most probably is an unknown corridor of Speleochatka cave (Fig.2).
In the profile 4 (Fig. 7) significant high resistivity bodies have been confirmed. Between 20 and $60 \mathrm{~m}$ of profile length exist the Józef cave, what is attested by speleologists. Measurement line has been designated to pass right in the vicinity of entrance to this cave which is seen at $55 \mathrm{~m}$ of profile. Right to this point there are two cave wells i.e. Kolumnowa and Asa which go down to a depth of $35 \mathrm{~m}$ below surface. At resistivity model they are present as a single, wide and up to $7000 \Omega \mathrm{m}$, anomaly. In reality Kolumnowa Well is $3 \mathrm{~m}$ wide at its maximum (Sanak 2011). In the middle of the same profile, high resistivity anomaly starting at depth of $10 \mathrm{~m}$ below surface, is identified as an Rysia cave. Together with Józef cave, it is connected by structure with resistivity over $2500 \Omega \mathrm{m}$. All these caves were formed by simultaneously running processes, so even if they are not connected by direct corridor it could be done by cracks and crevices. In the profiles 3 and 5 (Fig.6 and 8) similar structures as described before for profile 4 can be observed. Especially on resistivity cross section 3 (Fig.6) where anomalies differ only in terms of resistivity values, comparing to profile 4 . Even entrance to Józef cave is well preserved.

Low resistivity anomalies visible near the surface (between -70 to $-10 \mathrm{~m}$ ) on all profiles gradually reduce their thickness north west. Their origin is unclear and may be related to change of geological facies from limestone to marl. A similar interpretation may be applied to areas under level of occurring caves.

Under the most high resistive bodies generated by inversion the DOI values starts to increase. This indicates areas where importance growth of parameters of optimization equation is observed. In anomaly identified as Rysia cave, DOI rise drastically in its center while in similarly recorded Józef cave it grows on its side. Authors lean towards the concept that structures hidden in those studies behind DOI index above 0.4 are more complex as it is in case of Rysia cave 
characterized by multitude small corridors leaving the sides from main corridor or wells and Józefa cave that possess a relatively simple structure. It is indicator over complicated nature of Gieńkówka cave continuation which yet has to be confirmed by speleologists. In case of those areas with high DOI index values providing even the estimated depth of the bottom of the caves should not be considered as reliable.

\section{Acknowledgements}

The research has been partially supported by Young Researchers Project founded by University of Silesia. Special thanks for members of Speleological Club Olkusz for providing maps and their help in the field work.

\section{References:}

Buła Z. (2000) Lower Palaeozoic of Upper Silesia and the western Małopolska (Dolny Paleozoik Górnego Śląska i Zachodniej Małopolski), Pr. PIG.171, p. 63 (in Polish)

Dadlez R. Kowalczewski Z., Znosko J. (1994) Some key problems of the pre-Permian tectonics of Poland, Kwartalnik Geologiczny, 38: pp. 169-190.

Deceuster J., Etienne A., Tanguy R., Nguyen F., Kaufmann O. (2014) A modified DOIbased method to statistically estimate the depth of investigation of dc resistivity surveys, Journal of Applied Geophysics, 103, pp. 172-185

Gradziński M. (2013) Phreatic caves of the Polish Jura - palaeohydrological conditions of their origin, Materiały 47, Sympozjum Speleologicznego., Olsztyn. (In Polish).

Gradziński R. (1962) Development of underground karst forms in the southern part of the Cracow Upland (Rozwój podziemnych form krasowych w południowej części Wyżyny
Krakowsko-Częstochowskiej),.Rocznik

Polskiego Towarzystwa Geologicznego 32, pp. 429-492. (in Polish)

Ciołkiewicz A., Nowak J. (2013) Fulfilled Dreams Cave (Jaskinia Spełnionych marzeń), Jaskinie 72, (in Polish)

Jędrys J. (2007) Application of selected geophysical methods for identification of facies of Upper Jurassic formations in the Kraków-Częstochowa Upland (Zastosowanie wybranych metod geofizycznych do rozpoznawania facjalnego utworów górnojurajskich na wyżynie Krakowsko-Częstochowskiej), Rozprawa doktorska AGH, Kraków (in Polish)

Loke M.H. (2014) Tutorial: 2-D and 3-D electrical imaging; surveys in: http://www.geoelectrical.com (Website accessed 26.04.2014)

Loke M.H., Acworth I., Dahlin T. (2003) A comparison of smooth and blocky inversion methods in 2D electrical imaging surveys, Exploration Geophysics 34, pp. 182-187

Marescot L., Loke M.H., Chapellier D., Delaloye R.,Lambiel C., Reynard E. (2003) Assessing reliability of 2D resistivity imaging in mountain permafrost studies using the depth of investigation index method, Near Surface Geophysics, 1(2), pp. 57-67

Morawska A. (1997) The Lubliniec fracture zone: Boundary of the Upper Silesian and Małopolska Massifs, southern Poland. Ann. Soc. Geol. Polon. 67, pp. 429-437.

Oldenburg D. W., Jones F.H.M. (2007) Inversion for Applied Geophysics; Learning resources about geophysical inversion, University of British Columbia: Geophysical Inversion Facility, http://www.eos.ubc.ca/ubcgif/iag/index.ht m (Website accessed 26.04.2014)

Oldenburg D.W., Li Y. (1999) Estimating depth of investigation in dc resistivity and IP surveys, Geophysics 64(2), pp. 403-416. 
RES2DINV manual (2014) http://www.geoelectrical.com (Website accessed 26.04.2014)

Sanak A. (2011) Plan of Józef Cave, http://www.jaskiniejury.pl/listajaskin/jaskinie-wyzyny-krakowskoczestochowskiej/96-jozefa-402-metry (Website accessed 01.06.2014)

Stepišnik U. Mihevc A. (2008) Investigation of structure of various surface karst formations in limestone and dolomite bedrock with application of the electrical resistivity imaging, Acta carsologica, 2008, Vol 37, Issue 1, pp. 133-140

Żaba J. (1999) Structural evolution of the Lower Palaeozoic formations at the boundary of the Upper Silesia and Małopolska Blocks. (Ewolucja strukturalna utworów dolnopaleozoicznych w strefie granicznej bloków górnośląskiego i małopolskiego) Pr. PIG, p. 166 (in Polish) 